\title{
THE ENVIRONMENTAL LAW ENFORCEMENT: IN THE FRAMEWORK OF POSITIVE LAW AND ISLAMIC LAW
}

\author{
Andi Abu Dzar Nuzul \\ Graduate Student at Gajah Mada University (UGM) Yogyakarta \\ Email: achaboa420@gmail.com
}

\author{
Hamzah \\ Lecturer at IAIN Bone \\ Email: hamzahlatif122@gmail.com
}

\begin{abstract}
The environmental law enforcement is a form of re-actualization of the hopes and dreams of a good living environment. The portion and content of positive law in environmental law enforcement are sufficient in ensnaring perpetrators of environmental destruction. In Islamic law, environmental enforcement is something that must be guarded and preserved, this is stated in the Qur'an and hadith. This study is a literature study, which examines the legislation on environmental enforcement and text arguments relating to the environment. The approach in this study is a formal juridical approach to the scale of positive law and a normative approach to Islamic law. The findings in this study prove that the rules regarding environmental law enforcement in positive law are very adequate. In Law Number 32 of 2009, it has accommodated acts of environmental destruction that can be ensnared with administrative, civil and criminal offenses that lead to fines and imprisonment. Meanwhile, in Islamic law, law enforcement against environmental destruction in jinayah law is subject to ta'zir punishment or a sentence stipulated by the government. In the concept of benefit, environmental destruction needs to be enforced because it is against the benefit of human life and/or can threaten the survival of mankind. The implication of this finding is that environmental law enforcement has been regulated in environmental legislation and is very adequate, and this is in line with the concept of negligence in Islamic law, so that environmental violations need to be taken firmly in order to maintain environmental sustainability.

Penegakan hukum lingkungan merupakan bentuk reaktualisasi dari harapan dan impian terselenggarannya lingkungan hidup yang baik. Porsi dan muatan hukum positif dalam penegakan hukum lingkungan sudah cukup memadai dalam menjerat pelaku pengrusakan lingkugan. Dalam Hukum Islam penegakan lingkungan menjadi sesuatu yang harus dijaga dan dilestarikan, hal itu tertuang dalam Al-Qur'an dan hadis. Kajian ini merupakan kajian kepustakaan, yang
\end{abstract}


menalaah perundang-undangan tentang penegakan lingkungan hidup dan dalildalil nash yang berkaitan dengan lingkungan. Pendekatan dalam kajian ini adalah pendekatan yuridis formal untuk skala hukum positif dan pendekatan normatif untuk hukum Islam. Temuan dalam kajian ini membuktikan bahwa, aturan tentang penegakan hukum lingkungan dalam hukum positif sangat memadai. Dalam Undang-Undang No. 32 Tahun 2009 telah mengakomodir tindakan pengrusakan lingkungan dapat dijerat dengan pelanggaran administrasi, keperdataan dan jeratan pemidanaan yang berujung pada denda dan pemenjaraan. Sementara dalam hukum Islam, penegakan hukum terhadap pengrusakan lingkungan dalam hukum jinayah dijerat dengan hukuman ta'zir atau hukuman yang ditetapkan oleh pemerintah. Dalam konsep kemaslahatan, pengrusakan lingkungan perlu ditegakkan karena bertentangan dengan kemaslahatan hidup manusia dan atau dapat mengancam kelangsungan hidup manusia. Implikasi dari temuan ini bahwa, penegakan hukum lingkungan telah diatur dalam perundangundangan lingkungan dan sangat memadai, dan hal itu sejalan dengan konsep kemaslahan dalam hukum Islam, sehingga pelanggaran lingkungan perlu untuk ditindak tegas demi menjaga keberlangsungan lingkungan.

Keywords: Law Enforcement; Environment; Positive Law; Islamic Law.

\section{INTRODUCTION}

The formulation of policies related to environmental management is oriented towards fulfilling human needs without having to radically destroy the environment. Because basically, according to what is affirmed in Article $28 \mathrm{H}$ Paragraph (1) of the 1945 Constitution of the Republic of Indonesia that everyone has the right to live in physical and mental well-being, to have a place to live, and to have a good and healthy living environment and the right to obtain health services. For example, Article 65 Paragraph (1) states that everyone has the right to a good and healthy environment as part of human rights. A good and healthy living environment is a right for everyone, even this right has become part of human rights, so it must be maintained and preserved.

The forest fires that occur in Indonesia are evidence that environmental damage is not only caused by natural processes but is also caused by human and corporate negligence as legal subjects in Indonesia. The National Disaster Management Agency (BNPB) recorded that the total area of forest and land burned throughout Indonesia from January to August 2019 reached 328,724 hectares. The largest forest and land fires are in Riau Province. ${ }^{1}$ If the case of forest and land fires does not get intense attention from the Government, then cases like this will continue to occur and will gradually have a very bad effect on humans.

\footnotetext{
${ }^{1}$ Ekariana, BNPB Catat 328.724 Hektare Hutan dan Lahan Terbakar hingga Agustus, retrieved from katadata.co.id, on October $11^{\text {th }}, 2019$
} 
The environmental law enforcement is a big question mark. Environmental destruction which is concrete evidence of the weakness of environmental law enforcement. Even though the regulations are sufficient to ensnare the perpetrators of environmental destruction. However, it is unfortunate because the enforcement process did not go well. The urgency of enforcing environmental law is not only part of positive law, but in Islamic law it strongly recommends protecting the environment.

In connection with the foregoing, there are so many verses of the Qur'an and Hadith that talk about the necessity of preserving nature. If the values in the Islamic Sharia regarding the environment have been transformed into statutory regulations which are formed and implemented in order to regulate the environmental order in Indonesia. Among them are the calls and censure of Allah, against people who do damage on this earth and Allah, also saying that the perpetrators of destruction on this earth are the most disliked by Him and will be put into hellfire. ${ }^{2}$

Hence, it is urgent to reflect on law enforcement in positive law and Islamic law, this is to make clear legal arguments against perpetrators of environmental destruction. In addition, it becomes a reference in law enforcement that positive law and Islamic law have a correlation in law enforcement of environmental destruction. It is based on the existence of the earth or the environment that must be preserved, because of the huge consequences that can hit if there is environmental damage. So, environmental law enforcement is urgent to be discussed and implemented in society, as a hope and dream of positive law and Islamic law.

\section{DISCUSSION}

\section{A. Environmental Law Enforcement in The Positive Law}

According to Munadjat Danusaputro, environmental law is a law that underlies the implementation of protection, management and enhancement of environmental resilience. ${ }^{3}$ R. Seerden M. Heldeweg expressed his opinion regarding various instruments used in environmental management and protection. These instruments are like a chain (regulation chain) which includes: legislation, regulation, issueing permit, implementation, and enforcement. ${ }^{4}$

\footnotetext{
${ }^{2}$ See, the Qur'an surah Al-Qashash/28: 77.

${ }^{3}$ Muhammad Erwin, Hukum Lingkungan dalam Sistem Kebijaksanaan Pembangunan Lingkungan Hidup (Bandung: PT Refika Aditama, 2008), p. 9.

${ }^{4}$ Maradona ed. Laode M. Syarif dan Andri G. Wibisana, Hukum Lingkungan Teori, Legislasi, dan Studi Kasus (The ASIA Foundation: United States Agency for International Development (USAID), Pertnership), p. 494.
} 
Environmental law enforcement according to Hamzah that environmental law enforcement according to Nottie Handhaving Milieurecht is supervision and application or threats, the use of administrative, criminal, or civil instruments can achieve the arrangement of legal provisions and regulations that apply generally and individually. Supervision (control) means the supervision of the government to comply with the provision of regulations that are parallel to criminal law investigations. ${ }^{5}$ Environmental law enforcement is an effort to achieve compliance with regulations and requirements in the applicable environmental law provisions in general and individually, through supervision and application of administrative, civil and criminal sanctions. This understanding is in accordance with Biezeveld's opinion about environmental law enforcement which consists of several activities that:

Environmental law enforcement can be defined as the application of legalgovernmental powers to ensure compliance with environmental regulations by means of:

a) Administrative supervision of the compliance with environmental regulations (inspection) (mainly preventive activity);

b) Administrative measures or sanction in case of non-compliance (corrective activity); criminal investigation in case presumed offences (repressive activity);

c) Criminal measures or sanction in case of offences (repressive activity);

d) Civil action (lawsuit) in case of (threatening) non-compliance (preventive or corrective activity). ${ }^{6}$

The opinion above shows that there are three ways of enforcing law and applying sanctions in handling environmental issues, namely; administrative, civil, and criminal. Siswanto Sunarso explained about several ways of resolving environmental disputes, including out-of-court settlement, dispute resolution through court, dispute resolution through criminal justice. In environmental criminal cases related to criminal responsibility, there are rules on the application of the strict liability and vicarous liability doctrines. The principle of absolute responsibility (no-fault liability or liability without foul) in the literature is known as "absolute liability" or "strict liability". The principle of accountability without having to prove a mistake. A principle of responsibility that views "mistakes" as something irrelevant to be questioned. ${ }^{7}$

\footnotetext{
${ }^{5}$ Nina Herlina, Permasalahan Lingkungan Hidup dan Penegakan Hukum Lingkungan di Indonesia (Jurnal Ilmiah Galuh Justisi, 3(2), 2017), p. 162-176.

${ }^{6}$ Nina Herlina, Permasalahan Lingkungan Hidup, p. 162-176.

${ }^{7}$ Siswanto Sunarso, Hukum Pidana Lingkungan Hidup dan Strategi Penyelesaian Sengketa (Jakarta: PT Asdi Mahasatya, 2005), p. 141.
} 
The environmental disputes resolution is listed in Chapter XIII of the Law on Environmental Protection and Management (UUPPLH) Number 32 of 2009 concerning Environmental disputes resolution Article 84 Paragraph (1) which states that environmental dispute resolution can be pursued through the court or outside the court. Paragraph (3) continues the explanation from Paragraph (1) that a lawsuit through a court can only be pursued if the out-of-court dispute settlement effort is declared unsuccessful by one or the parties to the dispute.

The environmental dispute resolution outside the court is explained in Article 85 Paragraph (1) that; the environmental disputes resolution outside the court is conducted to reach an agreement regarding; (a) the form and amount of compensation; (b) remedial measures due to pollution and/or damage; (c) certain measures to ensure that pollution and/or damage will not be repeated; and/or (d) measures to prevent negative impacts on the environment.

Paragraph (3) also explains that in the environmental disputes resolution outside the court, the services of mediators and/or arbitrators can be used to help resolve environmental disputes. The environmental disputes resolution is also justified in the previous regulations. Law Number 23 of 1997 concerning Environmental Management (UUPLH 1997) and Law Number 4 of 1982 concerning Basic Provisions for Environmental Management (UUKPPLH 1982). It is regulated in that law that the environmental disputes resolution does not apply to criminal acts.

The environmental disputes resolution through the courts is confirmed in the third part of the UUPPLH. The interpretative method can determine the subject of environmental disputes, namely the disputing parties. Although it is realized that in the implementation of sustainable development, the most important thing is: "how to prevent dispute, not how to settle dispute" in accordance with the adage: "prevention is better than cure", and the adage that cannot be denied is true: "an ounce of prevention is worth a pound of cure". The objectives of regulating the environmental disputes resolution include, among others, so that environmental pollution and damage can be stopped, compensation can be provided, the person in charge of business/activity obeys the laws and regulations in the environmental sector and environmental restoration can be carried out.

The environmental disputes resolution through courts according to UUPPLH 2009 has regulated several things including environmental compensation and restoration, absolute responsibility, expiration dates for filing claims, local

${ }^{8}$ Siti Sundari Rangkuti, Hukum Lingkungan dan Kebijaksanaan Lingkungan Nasional, (Surabaya: Airlangga University Press, 1996), p. 247. 
government suing rights, community suing rights, environmental organizations' lawsuit rights, and administrative lawsuits . Meanwhile, the 1997 UUPLH only regulates the issue of compensation, the issue of responsibility, the expiration of the lawsuit filing, and the issue of the rights of the community and environmental organizations to file a lawsuit.

Article 90 UUPPLH provides arrangements for a representative lawsuit which is a symbol of the progress of the UUPPLH and is the first lawsuit against class action in Indonesia. The recognition of class action by UUPPLH clearly requires juridical adjustments to the applicable civil procedural law. Class action should not be confused with non-governmental organizations (LSM) or Environmental Organizations (OLH). Articles 90, 91, 92 of the UUPPLH provide arrangements regarding the right to sue ius standi-standing to sue or legal standing of environmental organizations. ${ }^{9}$

\section{1) The Environmental Administration Law Enforcement}

According to Philip M. Hadjon, administrative law regulates the means for the ruler to regulate and control society, regulates ways of citizen participation in the regulatory and controlling process, protects the law and establishes fundamental norms for the ruler for good governance. ${ }^{10}$ Handling environmental problems and enforcing preventive law through administrative legal means occupy an important position, because their functions are based on the abatement at the source principle. So that the process of law enforcement through administrative legal means is considered more fulfilling the function of protecting "the right to a good and healthy environment" as a constitutional right. ${ }^{11}$

Article 36 Paragraph (1) also confirms that every business and or activity that is required to have an Environmental Impact Analysis (AMDAL) or Environmental Management Effort (UKL) and Environmental Monitoring Effort (UPL) must have an environmental permit, and it is further mentioned in paragraph (4) that the environmental permit is issued by the Minister, Governor or regent/mayor in accordance with their respective authorities. Article 76 (2) UUPPLH 2009 recognizes four types of administrative sanctions, namely written warning, government coercion, suspension of environmental permits or revocation of environmental permits.

\footnotetext{
${ }^{9}$ Triwanto, Penyelesaian Sengketa Lingkungan Hidup Menurut Undang-Undang Nomor 32 Tahun 2009 (Wacana Hukum Vol. Number 1, April 2009), p. 86-102

${ }^{10}$ Philip M. Hadjon, PengantarHukumAdministrasi Indonesia (Yogyakarta: Gajah Mada University Press, 2002), p. 27.

${ }^{11}$ Kartono, Penegakan Hukum Lingkungan Administratif dalam Undang-Undang Perlindungan dan Pengelolaan Lingkungan Hidup (Jurnal Dinamika Hukum Vol. 9 Number 3, September 2009), p. 248 257.
} 
Government coercive sanctions and fines are administrative sanctions that are quite effective in controlling environmental pollution and/or destruction. Government coercion is a real and very direct action by the government to end conditions that are prohibited by a rule of administrative law, for example the act of ordering to remove, obstruct and restore to its original state.

Administrative sanctions in the form of suspension environmental permits are quite heavy because if the environmental permits are suspended, the process of activities and/or businesses is temporarily suspended. The heaviest administrative sanction is the sanction of revoking environmental permits. With the revocation of the environmental permit, all business processes and/or activities are permanently terminated unless a new environmental permit is issued. ${ }^{12}$ Environmental permits can also be canceled in accordance with the explanation in Article 38 that in addition to the provisions referred to in Article 37 Paragraph (2), environmental permits can be canceled through a state administrative court decision.

\section{2) The Environmental Civil Law Enforcement}

The resolution of civil disputes in the environment can be pursued through the court and outside the court. This is explained in the General Explanation point 5 of the second paragraph of the Law Number 32 of 2009 that "the provisions of civil law include the environmental disputes resolution outside the court and inside the court. The environmental disputes resolution in court includes class action suits, environmental organizations' lawsuit rights, or government lawsuit rights. Through these methods, it is hoped that in addition to having a deterrent effect on perpetrators of environmental destruction, it will also increase the awareness of all stakeholders about the importance of environmental protection and management for present and future generations".

The civil aspect in environmental law is one aspect of environmental law enforcement. Pollution and environmental damage occur, then there are victims of pollution and destruction, in the sense of being the injured party, and the injured party can be an individual, the community or the state. UUPPLH environmental law enforcement process through civil procedure is regulated in CHAPTER XIII Article 84 to Article 93. The civil aspects listed in this Article contain the environmental disputes resolution that can be pursued through court (litigation) or outside court (non-litigation) based on voluntary choice by the disputing parties. This provision is intended to protect the civil rights of the disputing parties. ${ }^{13}$

\footnotetext{
${ }^{12}$ Ruslan Renggong, Hukum Pidana Lingkungan (Jakarta: Pernadamedia Grup, 2018), p. 91.

${ }^{13}$ Made Nikita Novia Kumalasari dan I Made Udiana, Penegakan Hukum Lingkungan Menurut Aspek Perdata (Jurnal Kertha Semaya: Faculty of Law, Udayana University, Vol. 6, Number
} 7, 2018), p. 4. 
One of the environmental disputes resolution through civil law is by using Alternative Dispute Resolution (ADR). ADR institutions are arbitration, mediation, negotiation, and conciliation, which are currently widely used by industrialists in the environmental disputes resolution in Indonesia, especially in cooperation agreements between investors and the community, in the event of environmental problems. ${ }^{14}$ Article 86 also affirms that the government and/or the community can establish a free and impartial environmental service provider for environmental dispute resolution services.

\section{3) The Environmental Criminal Law Enforcement}

The environmental law enforcement through criminal law instruments as specified in the general explanation of point 6 of Law Number 32 of 2009 that "criminal law enforcement in this Law introduces the threat of minimum and maximum penalties, expansion of evidence, penalties for violations of quality standards, integrated criminal law enforcement and the regulation of corporate crime. The environmental criminal law enforcement still observes the principle of ultimum remedium which obliges the application of criminal law enforcement as a last resort after the implementation of administrative law enforcement is deemed unsuccessful. The application of the ultimum remedium principle only applies to certain formal crimes, namely punishment for violations of wastewater quality standards, emissions, and disturbances. What is meant in the principle of ultimum remidium in environmental law enforcement is to place criminal law as the last means of resolving environmental disputes if administrative law and civil law facilities have not succeeded in resolving environmental disputes that have occurred.

The second purpose of punishment is "deterrence". The term "deterrence" according to Zimring and Hawkins, is used more limited to the application of punishment in a case, where the threat of punishment makes a person feel afraid and refrain from committing a crime. However, the "net deterrence effect" of this particular threat to a person can also be a threat to the whole society not to commit a crime. ${ }^{15}$ The criminal provisions that exist in Law Number 32 of 2009, even though this Law is an Umbrella Act. The criminal provisions remain on the grounds that law enforcement in Indonesia will not be separated from criminal law instruments. Therefore, the environmental law enforcement also needs to go through criminal law, so that Law Number 32 of 2009 contains complete criminal

\footnotetext{
${ }^{14}$ Sodikin, Politik Hukum Penegakan Hukum Lingkungan (Jakarta: Djambatan, 2007), p. 94.

${ }^{15}$ Mahmud Mulyadi, Criminal Policy: Pendekatan Integral Penal Policy dan Non-Penal Policy dalam Penanggulangan Kejahatan Kekerasan (Medan: Pustaka Bangsa Press, 2008), p. 65-88.
} 
provisions. ${ }^{16}$ Although many criminal law enforcement in the environmental sector has not been resolved with various problems, including; (1) Existing regulations and policies cannot solve the problem of environmental crimes in particular; (2) Law Number 23 of 1997 in conjunction with Law Number 32 of 2009 cannot be an effective instrument to protect the environment. ${ }^{17}$

In formal juridical terms, environmental law enforcement is regulated in Article 98 of Law Number 32 of 2009 concerning Environmental Protection and Management which states:

1) Anyone who deliberately commits an act that results in exceeding the air quality standard, ambient quality standard, water quality standard, sea water quality standard, or environmental damage standard criteria, will be sentenced to imprisonment for a minimum of 3 (three) years and a maximum of 10 (ten) years and a fine of at least Rp. 3,000,000,000.00 (three billion rupiahs) and a maximum of Rp. 10,000,000,000.00 (ten billion rupiahs).

2) If the act as referred to in paragraph (1) results in a person being injured and/or a danger to human health, the punishment shall be imprisonment for a maximum of 4 (four) years and a maximum of 12 (twelve) years and a fine of at least $\mathrm{Rp.} 4,000,000,000.00$ (four billion rupiahs) and a maximum of $\mathrm{Rp}$. $12,000,000,000.00$ (twelve billion rupiahs).

3) If the act as referred to in paragraph (1) results in a serious injury or death, the person shall be punished with imprisonment for a minimum of 5 (five) years and a maximum of 15 (fifteen) years and a fine of at least Rp. $5,000,000,000.00$ (five billion rupiahs) and a maximum of $\mathrm{Rp}$. $15,000,000,000.00$ (fifteen billion rupiahs). ${ }^{18}$

The threat of punishment as stated in Law Number 32 of 2009 concerning Environmental Protection and Management is imprisonment and fines. Apart from that there are additional penalties or disciplinary actions against business entities in Article 119 in the form of; (a) Deprivation of profits derived from a criminal act; (b) The closure of all or part of the place of business and/or activity; (c) Correction due to criminal acts; (d) The obligation to do what was neglected without the right; (e) The placement of the company under the supervision of a maximum of 3 (three) years.

${ }^{16}$ Sodikin, Penegakan Hukum Lingkungan Menurut Undang-undang Nomor 32 Tahun 2009 Tentang Perlindungan Dan Pengelolaan Lingkungan (KANUN Number 52, December 2010 Edition), p. 543-563.

${ }^{17}$ Bawono, B. T., \& Mashdurohatun, A. Penegakan Hukum Pidana di Bidang Illegal Logging Bagi Kelestarian Lingkungan Hidup dan Upaya Penanggulangannya (Jurnal Hukum, 26(2), 2020), p. 590 611.

${ }^{18}$ Law Number 32 of 2009 concerning Environmental Protection and Management 


\section{B. The Environmental Law Enforcement in Islamic Law}

Islam was revealed by Allah as rahmatallil alamin ${ }^{19}$ (the mercy to the whole universe). Rahmat in Arabic means love or affection. This shows that Muslims wherever and whenever they must always love. And his love is not only for certain circles or certain creatures but for all nature, including the environment. In many historical records, many mentioned how the Prophet Muhammad (pbuh) gave many examples and taught the importance of noble morals for every good Muslim and for his fellow humans by always maintaining his attitude and words, towards jinn by not urinating in small holes which are possible places to live for them, to animals that will be slaughtered by sharpening knives so as not to torture, including to the environment even during war with the prohibition of cutting down trees and damaging buildings. Rasulullah (pbuh) once said: "If the apocalypse happens tomorrow, while in your hand you have date seeds, so if you are able to plant them before the apocalypse occurs, plant them" (Hadits narrated by Ahmad).

Likewise with a grandfather who was met by caliph Harun al Rashid while planting a date palm tree. Logically, the grandfather could not enjoy the crops because he was so old. So, the caliph suggested that grandfather plant plants that were shorter in terms of yields. But the grandfather lightly said that what he planted was deliberately so that his children and grandchildren could enjoy it later.

In the Islamic perspective, humans and the environment have a very close relationship because Allah created this universe, including humans and the environment in balance and harmony. This balance and harmony must be maintained so as not to be damaged. The continuity of life in this world is also interrelated, if one component experiences extraordinary disturbances it will affect the other components.

In the perspective of environmental ethics, the most important component of the relationship between humans and the environment is the protection of humans, the purpose of religion is to protect, safeguard and care for religion, life, reason and mind, children and grandchildren and character as well as care for equality and freedom. Protecting and caring for the environment is the main goal of the relationship.

If the environmental situation continues to deteriorate, in the end life will cease to exist, of course religion will no longer exist. ${ }^{20}$ Humans are the dominant factor in changes in the good and bad environment and everything that happens in the environment and nature. The Qur`an explained that the environmental

\footnotetext{
${ }^{19}$ The Qur'an surah Al-Anbiya verse 107. The translation "And We have not sent you, $(\mathrm{O}$ Muhammad), except as a mercy to the worlds".

${ }^{20}$ Alef Theria Wasim, Ekologi Agama dan Studi Agama-agama (Yogyakarta: Oasis Pulisher, 2005), p. 78.
} 
damage both on land and at sea the perpetrator is human, ${ }^{21}$ because human exploitation is not limited to fulfilling the need to survive. Considering environmental sustainability and natural balance but based more on economic factors, power, and endless desire fulfillment.

Due to the dominant factor of humans towards nature, especially the environmental damage that exists, Allah reminds us in the Qur'an surah Al-a `raf verse/7:56:

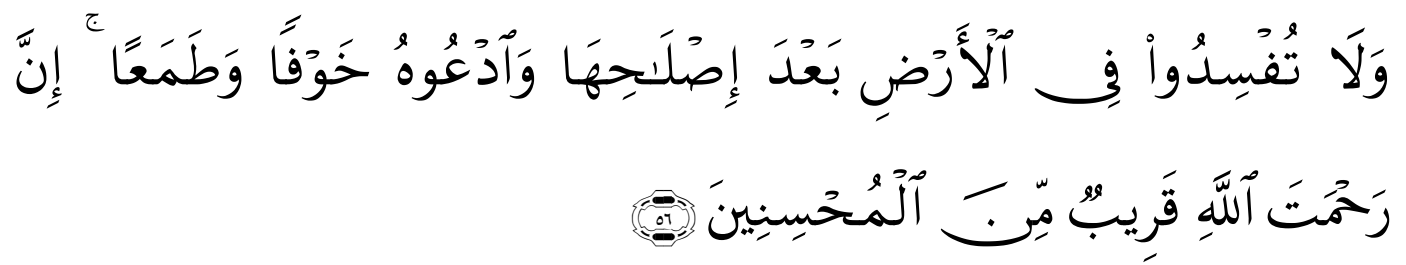

The translation: And cause not corruption upon the earth after its reformation. And invoke Him in fear and aspiration. Indeed, the mercy of Allah is near to the doers of good. ${ }^{22}$

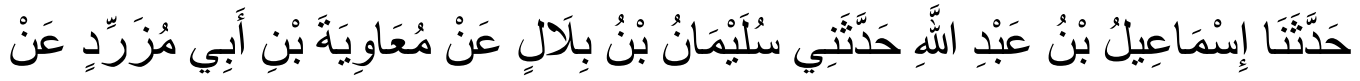

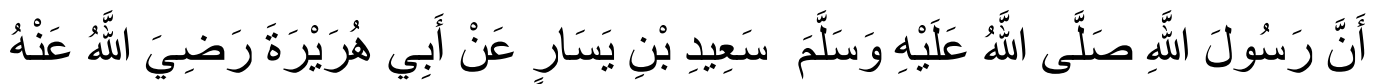

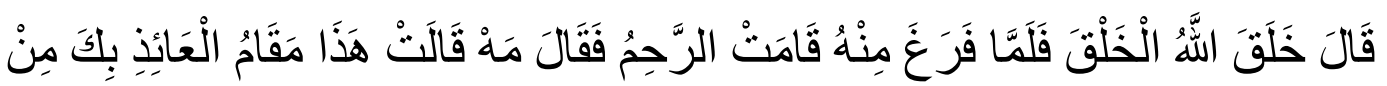

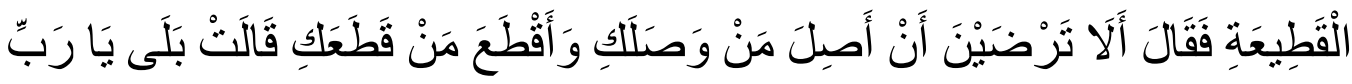

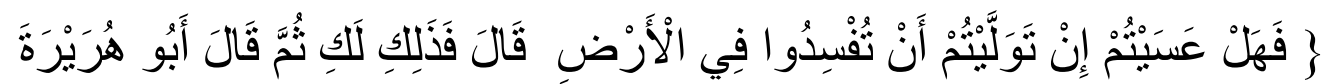

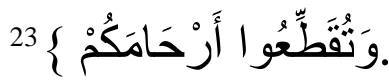

The meaning: Has told us Ismail bin Abdullah has told me Sulaiman bin Bilal from Mu'awiyah bin Abu Muzarrad from Sa'id bin Yasar from Abu Hurairah radliyallahu'anhu, "Rasulullah sallallahu 'alaihi wasallam said:" Allah created man, when He finished from creation, the womb stands up and says, 'Know this, this is the position that takes refuge in You from being cut off.' Then Allah said: 'Aren't you pleased if I connect whoever connects you and I cut off whoever cuts you off?' So, the uterus answers, 'Yes, rabb.' Then Allah said,

${ }^{21}$ The Qur'an surah Ar-Ruum verse 41. The translation "Corruption has appeared throughout the land and sea by (reason of) what the hands of people have earned so He may let them taste part of (the consequence of) what they have done that perhaps they will return (to righteousness).

${ }^{22}$ Kementerian Agama RI, Al-Qur'an dan Terjemahnya (Bandung: CV Penerbit Jamanatul Ali-Art (J-ART), 2004), p. 99.

${ }^{23}$ Imam Bukhari, Shahih al-Bukhari, Dar al-Biya al-Kutub al-'Arabiyyah. 1981, Book of Tawheed Hadith Number 6948. 
'That is for you.' Then Abu Hurairah read the verse: '(Will you be in power you will do damage to the earth and cut off the connection of your wombs?)'.

The obligation of humans to protect the environment is also closely related to the position of humans as khalifah on earth ${ }^{24}$ in Arabic it means the representative of Allah on earth. So, humans have the responsibility to manage the earth as well as possible as a mandate given by Allah. According to Quraish Shihab this caliphate has three interrelated elements, then added with a fourth element that is outside, but very much determines the meaning of the khalifah in the view of the Qur'an. The three elements (1) Humans, in this case the caliph; (2) The universe, which Allah designated as earth; ${ }^{25}$ (3) The relationship between humans and nature and everything in it, including humans (istikhlaf or duties of the khalifah).

Those are the three elements that are interrelated while the fourth element that is outside is the one who gave the assignment, namely Allah. In this case the person assigned must pay attention to the will of the person assigned to him. The relationship between humans and nature or the relationship between humans and each other is not a relationship between the conqueror and the conquered or between the master and the servant, but the relationship of togetherness in submission to Allah. Because the human ability to manage is not the result of the strength they have but the gift of Allah. ${ }^{26}$ This is illustrated in the Qur'an surah Ibrahim/14: 32:

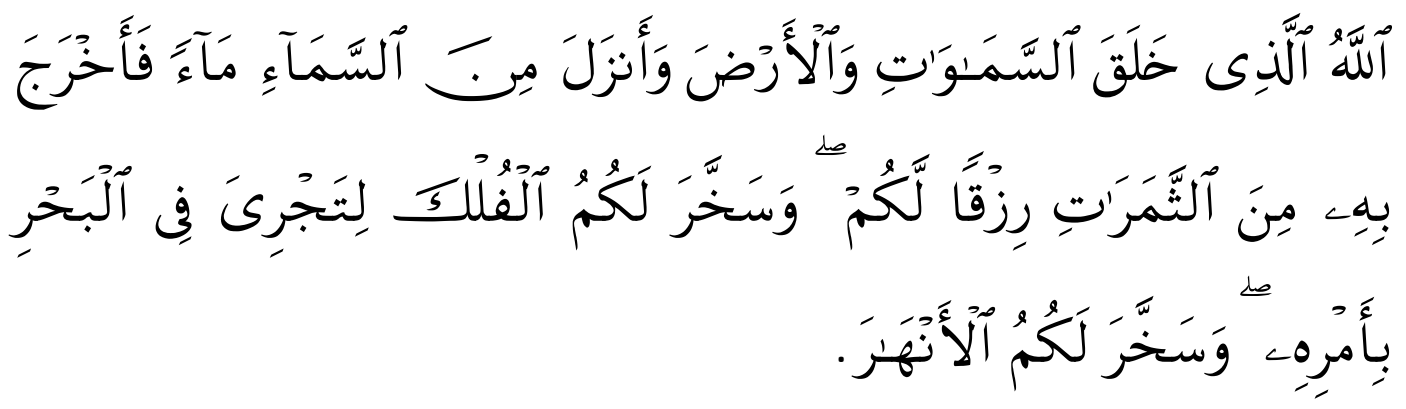

The translation: It is Allah who created the heavens and the earth and sent down rain from the sky and produced thereby some fruits as provision for you and subjected for you the ships to sail through the sea by His command and subjected for you the rivers. ${ }^{27}$

\footnotetext{
${ }^{24}$ See the Qur'an surah Al-Baqarah/2:30

${ }^{25}$ The Qur'an surah Al-Baqarah/2: 22. The translation: "(He) who made for you the earth a bed (spread out) and the sky a ceiling and sent down from the sky, rain and brought forth thereby fruits as provision for you. So do not attribute to Allah equals while you know (that there is nothing similar to Him)".

${ }^{26}$ Quraisy Shihab, Membumikan Al-Qur`an (Bandung: Mizan, 1999), p. 295.

${ }^{27}$ Retrieved from https://quran.com/14/32-42
} 
The Qur'an Surah Az-Zukhruf/43:13.

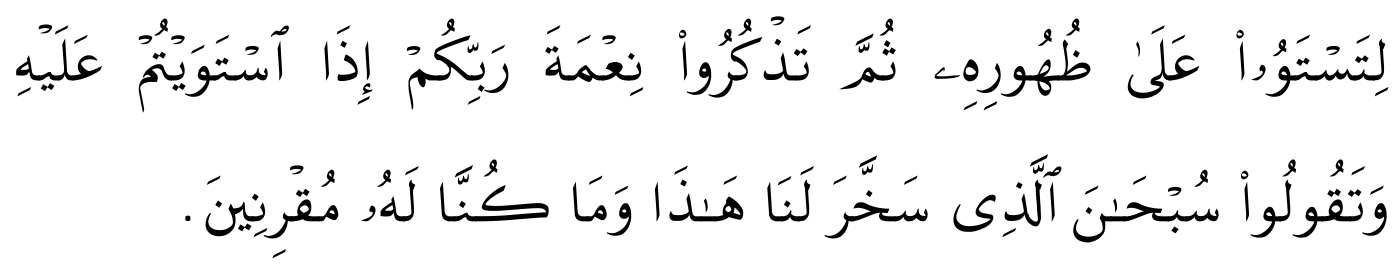

The translation: That you may settle yourselves upon their backs and then remember the favor of your Lord when you have settled upon them and say. "Exalted is $\mathrm{He}$ who has subjected this to us, and we could not have (otherwise) subdued it. ${ }^{28}$

There are two basic teachings that Muslims must cultivate in relation to environmental ethics. The first is rabbul alamin. Islam teaches that Allah swt is the God of the worlds. So, it is not God for humans or a group of humans alone. But the God of all worlds, and nature before God, is the same. Semuanya dilayani oleh Allah sama dengan manusia. Second, rahmatan lil alamin. This means that humans are given the mandate to manifest all their behavior in the context of compassion for all nature. Man acts in all his actions out of compassion for all nature. If the meaning of rabbul alamin and rahmatan lil alamin is well understood, it will not damage the natural environment.

So far, there are five components of life that must be maintained by all humans, namely hifdzul nafs (guarding the soul), hidzul aql (maintaining mind), hidzul maal (safeguarding wealth), hidzul nasl (maintaining descent) and hifdzud diin (maintaining religion). According to Ali Yafie, this is now a big problem and must be given a place for its development, namely environmental damage. So, if we say that there needs to be hidzul nafs or hifdzud diin, now we should go to the basis of religion, namely hifdzul bi ah (protecting the environment). In religion, there are three levels or process tasks that must be passed so that it is complete. First, ta a abbud means that we pray, fast or hajj is only ta `abbud which means to show our obedience to Allah's guidance. Second, Ta'qqul means using the brain to understand worship. What is the order of ablution for? To be clean. What is the dress order for? In order to become an honorable human by covering one's genitals. Third, takhalluq means that worship must be made into akhlak. Worship must be made morals. It is unfortunate if the lesson on the thaharah chapter is only if you want to pray but not made into akhlak. In fact, the thaharah chapter also talks about environmental cleanliness. ${ }^{29}$

\footnotetext{
${ }^{28}$ Retrieved from https://quran.com/43/13-23

${ }^{29}$ Ali Yafie, Menjaga alam wajib hukumnya (Republika, Friday, February $9^{\text {th }}, 2007$ ).
} 
In being completely religious, it can become a basis for environmental ethics from an Islamic perspective. First is ta ${ }^{\circ}$ abbud. That protecting the environment is the implementation of obedience to Allah. Because protecting the environment is part of the mandate of humans as a khalifah. Even in the science of fiqh, maintaining the sustainability and balance of the environment in a mandatory legal state because the commands are clear both in the Qur' an and the hadith of the Prophet (pbuh). According to Ali Yafie, environmental problems in fiqh science are included in the jinayat (criminal) chapter so that if someone does damage to the environment, they can be subject to sanctions or punishment. Second is ta aqquli.

The command to maintain the environment logically and intellectually serves a very understandable purpose. The environment is a place to live and place living things. The natural environment has been designed in such a way by Allah with balance and harmony and interrelation with one another. If there is an imbalance or damage done by humans. Then it will cause a disaster that will not only befall humans themselves but all creatures that live and live in that place will perish. Third is takhalluq. Protecting the environment must be the akhlak and habits of everyone. Because maintaining this environment is very easy and very beautiful when it comes from the habits or daily lives of every human being so that the balance and preservation of nature will occur automatically without the threat of punishment and other causes with certain lure.

Islamic law prioritizes goodness, benefit, welfare, and happiness of human life, keeping away depravity, damage and difficulties of life. The benefits of human life, both as individuals and as members of society, both the benefits of the afterlife and the benefits of the worldly life are at the core of the principles affirmed in Islamic law. Even the benefit of mankind is the main objective of Islamic law. The main objective of Islamic law is to realize the benefit of human life, and this benefit includes three graduations, namely (1) The benefit that must exist in human life, which is called the benefit of dlaruriyat which consists of the benefit of religion, the benefit of the soul, the benefit of reason, the benefit of descendants, and the benefit of property, (2) Benefits of Hajiyat, namely benefits related to the needs of human life, (3) Benefits of Tahsiniyat, namely benefits relating to the beauty of life. ${ }^{30}$ In the environment destruction is considered to be contrary to the benefit of human life, because it can cause greater damage and threaten human life.

Seeing the many contents of the Qur'an that discusses the command to protect the environment, we as Muslims should be willing to realize and reflect on

\footnotetext{
${ }^{30}$ Abdul Manan, Pencemaran Dan Perusakan Lingkungan dalam Perspektif Hukum Islam (Environmental Pollution and Damage in Islamic Law Perspective) (Jurnal Hukum dan Peradilan, Volume 4, Number 2, July 2015), p. 235.
} 
what is contained in the Qur'an. Hopefully with the growing awareness of Muslims in practicing religion, especially regarding the command to maintain natural balance, they can control the processing of existing natural resources wisely. ${ }^{31}$

Damage to nature or the environment is the result of human actions. Because humans who are given the responsibility as the khalifah on earth have abused the mandate. Humans have the initiative and creative power, while other creatures do not have it. Human excess being abused causes environmental damage that is getting worse. Human neglect and domination of nature and irregular processing of the environment make all elements of harmony and things that grow naturally turn into chaos and often end in disaster. In the word of Allah, Allah has determined and described the consequences of human iniquity against His Sharia. Humans can only drain and dig the contents of the earth without paying attention to its impact. Then there was disaster and destruction on the face of the earth. Yet all of that, according to Allah, is the result of human hands. So that human ethics should be emulated as guardian creatures on this earth as the environment. ${ }^{32}$

It is the human responsibility to maintain the continuity of these creatures that underlies the Prophet Muhammad (pbuh) to reserve pristine lands. Rasulullah (pbuh) once announced to his followers about an area as an area that should not be cultivated. The protected area is known in Sharia as hima. Rasulullah (pbuh) reserved hima solely to protect the ecosystem of a place so that the sustainability of the creatures that live in it can be fulfilled. Therefore, the Prophet (pbuh) should follow the example of the Prophet (pbuh) in preserving the environment.

Islamic law does not explicitly explain law enforcement against environmental polluters. However, in Islam there are many threats that are emphasized in the Qur'an as a result of environmental damage that can overtake humans. In Islamic criminal law, in relation to environmental law enforcement, it is up to the government to stipulate it or it is known as ta'zir law. So, it does not mean that Islamic law does not recognize it, but it is given to the government to determine it because it is not explained in detail in the Qur'an.

\section{CONCLUSION}

The environmental law enforcement in positive law is regulated in Law Number 23 of 2009 concerning Environmental Protection and Management. Juridically, environmental law enforcement has described threats to environmental destruction, both in civil administrative and criminal forms. The heaviest penalties in law enforcement in Indonesia as stipulated in the environmental law are the

\footnotetext{
${ }^{31}$ Quraisy Shihab, Membumikan Al-Qur`an, p. 71.

${ }^{32}$ See the Qur'an surah Ar-Ruum verse 41.
} 
threat of fines and imprisonment that are in accordance with the level of the violation committed. Meanwhile in Islamic law, environmental law enforcement is very much in line with the philosophical values of Islamic law in the benefit of human life. The greatest threat to the perpetrators of destruction on earth will be rewarded with hell. Meanwhile, in relation to Islamic criminal law (jinayah), the perpetrator of environmental destruction as a form of environmental law enforcement is ta'zir punishment, which is a law stipulated by the government. Thus, positive law and Islamic law are very much in line with law enforcement against environmental destruction. The consistency of the government in upholding environmental law is an absolute thing to uphold as the reimplementation of the goals in positive law and Islamic law.

\section{REFERENCES}

Bawono, B. T., dan Mashdurohatun, A. Penegakan Hukum Pidana Di Bidang Illegal Logging Bagi Kelestarian Lingkungan Hidup Dan Upaya Penanggulangannya. Jurnal Hukum, 26(2), 2020.

Ekariana. BNPB Catat 328.724 Hektare Hutan dan Lahan Terbakar hingga Agustus, retrieved from Katadata.co.id on October $11^{\text {th }}, 2019$.

Erwin, Muhammad. Hukum Lingkungan dalam Sistem Kebijaksanaan Pembangunan Lingkungan Hidup. PT Refika Aditama, Bandung 2008.

Hadjon, Philip M. Pengantar Hukum Administrasi Indonesia. Yogyakarta: Gajah Mada University Press, 2002.

Herlina, Nina. Permasalahan Lingkungan Hidup dan Penegakan Hukum Lingkungan di Indonesia. Jurnal Ilmiah Galuh Justisi, 3(2), 2017.

Imam Bukhari, Shahih al-Bukhari, Dar al-Biya al-Kutub al-Arabiyyah. 1981, Book of Tawheed Hadith Number 6948.

Kartono. Penegakan Hukum Lingkungan Administratif Dalam Undang-Undang Perlindungan Dan Pengelolaan Lingkungan Hidu. Jurnal Dinamika Hukum Vol. 9 Number 3, September 2009.

Kumalasari, Made Nikita Novia dan I Made Udiana. Penegakan Hukum Lingkungan Menurut Aspek Perdata. Jurnal Kertha Semaya: Faculty of Law, Udayana University, Vol. 6, Number 7, 2018.

Law Number 32 of 2009 concerning Environmental Protection and Management

Manan, Abdul. Pencemaran Dan Perusakan Lingkungan dalam Perspektif Hukum Islam (Environmental Pollution and Damage in Islamic Law Perspective). Jurnal Hukum dan Peradilan, Volume 4, Number 2, July 2015. 
Maradona ed. Laode M. Syarif dan Andri G. Wibisana. Hukum Lingkungan Teori, Legislasi, dan Studi Kasus, United States Agency for International Development (USAID), Pertnership, The ASIA Foundation.

Mulyadi, Mahmud. Criminal Policy: Pendekatan Integral Penal Policy dan Non-Penal Policy Dalam Penanggulangan Kejahatan Kekerasan. Medan: Pustaka Bangsa Press, 2008.

Rangkuti, Siti Sundari. Hukum Lingkungan dan Kebijaksanaan Lingkungan Nasional. Surabaya: Airlangga University Pres, 1996.

Renggong, Ruslan. Hukum Pidana Lingkungan. Jakarta: Pernadamedia Grup, 2018.

Shihab, Quraisy. Membumikan Al Qur`an. Bandung: Mizan, 1999.

Sodikin. Penegakan Hukum Lingkungan Menurut Undangundang Nomor 32 Tahun 2009 Tentang Perlindungan Dan Pengelolaan Lingkungan. KANUN Number 52, December 2010 Edition.

Sodikin. Politik Hukum Penegakan Hukum Lingkungan. Jakarta: Djambatan, 2007.

Sunarso, Siswanto. Hukum Pidana Lingkungan Hidup dan Strategi Penyelesaian Sengketa. Jakarta: PT Asdi Mahasatya, 2005.

Triwanto. Penyelesaian Sengketa Lingkungan Hidup Menurut Undang-Undang Nomor 32 Tahun 2009. Wacana Hukum Vol. Number 1, April 2009.

Wasim, Alef Theria. Ekologi Agama dan Studi Agama-agama. Yogyakarta: Oasis Pulisher, 2005.

Yafie, Ali. Menjaga alam Wajib Hukumnya. Republika, Friday, February 9 $9^{\text {th }}, 2007$. 